\title{
MULTI-ZONE MODELS OF COMBUSTION AND HEAT TRANSFER PROCESSES IN SI ENGINES
}

\section{JIŘí HVĚZDA}

Czech Technical University, Technická 4, 16607 Praha 6, E-mail: jiri.hvezda@fs.cvut.cz

Motor System s.r.o., Machkova 587, 50011 Hradec Králové, E-mail: hvezda@motorsystem.cz

\section{SHRNUTí}

Tato práce představuje sadu nově vyvinutých nástrojů implementovatelných do komplexních kódů pro simulaci spalovacích motorů pro zajištění výpočtů týkajících se vysokotlaké části termodynamického cyklu čtyřdobého zážehového motoru. Tento více-zónový simulační nástroj pracuje na základě jednoduché kvazi-dimenzionální metody reflektující reálnou geometrii spalovacího prostoru a použivá specifický prístup k popisu chemické transformace složek.

$\checkmark$ prípadech abnormálně rychlých chemických reakcí je klasické kinetické schéma adaptivně kombinováno s flexibilní metodou chemické rovnováhy pro zlepšení numerických vlastností soustavy rovnic.

Reálná 3-D geometrie spalovacího prostoru je zohledňována pomocí předem vytvořených geometrických charakteristik. Je zde prezentován nový univerzální nástroj zajištujuící tato data.

Nový kód má schopnost pracovat v prediktivním stejně jako inverzním módu. Vybrané výsledky týkající se obou těchto režimů jsou prezentovány v závěru príspěvku.

KLIĆCVÁ SLOVA: ZÁŽEHOVÝ MOTOR, ZÓNOVÝ MODEL, PREDIKTIVNÍ MODEL, INVERZNÍ MODEL, CHEMICKÁ KINETIKA, CHEMICKÁ ROVNOVÁHA, GEOMETRIE SPALOVACÍHO PROSTORU, SIMULACE.

\section{ABSTRACT}

The paper introduces a recently developed toolset to be implemented into the complicated simulation codes for combustion engines to treat the calculations concerning the high-pressure part of the thermodynamic cycle in a four-stroke spark ignition engine. This multi-zone simulating tool works on the basis of a simple quasi-dimensional method reflecting the real combustion chamber geometry and uses a specific approach to describe the species chemical transformation.

Here a standard kinetic scheme is combined adaptively with a flexible method for chemical equilibrium in the cases of abnormally fast chemical reactions to improve the numerical performance of the equation system.

Real 3-D combustion chamber geometry is taken into account by means of geometrical characteristics created in advance. A newly generalized tool providing these data is presented here.

The new code is also able to work in predictive or inverse mode. The selected results regarding these two points are presented at the end. KEYWORDS: SI ENGINE, ZONE MODEL, PREDICTIVE MODEL, INVERSE MODEL, CHEMICAL KINETICS, CHEMICAL EQUILIBRIUM, COMBUSTION CHAMBER GEOMETRY, SIMULATION.

\section{INTRODUCTION}

The simulation of a high-pressure part of the thermodynamic cycle in a four-stroke combustion engine is a complicated task, in which a number of scientific fields such as thermodynamics, chemistry and aerodynamics are involved. A complex solution is not simple, and the set of to date extreme approaches can be seen here.

On the one hand, there are detailed models reflecting the real combustion chamber geometry on the basis of CFD simulation providing very detailed results with velocity, temperature and concentration fields. Unfortunately, the significant computational time demand of these simulations restricts their wider application for regular simulations and even for optimizing calculations. On the other hand, the simplified codes using too low a number of the solved volumes also exist, which do not provide sufficiently detailed temperature and concentration data essential for application of the more sophisticated methods dealing with chemical kinetics. 
As a result, there is a strong and general demand for simulating code dealing with a high-pressure part of thermodynamic cycle in a four-stroke combustion engine, which should:

- be focused on direct spark ignition engines at first

- settle the numerical issues regarding the chemical transformation of fuel

- take into account real combustion chamber geometry

- work with predictive as well as inverse algorithm

- be implemented as a user's model to a complicated combustion engine simulating tool

- have the potential to improve knocking phenomenon study and its prediction

- provide its easy calibration using experimental data and its results extrapolation

- be fast in order to save computational time

- be sufficiently accurate

- reflect the user's low hardware and software capacities

- have the ability to be expanded to the area of pre-chamber spark ignition engines, dual fuel and compression ignition engines.

In general, the multi-zone models of combustion and heat transfer processes in SI engines [1] have great potential to represent a fast, accurate and stable simulation tool. Their physical basis, which corresponds well to a real flame front propagation, makes them easy to calibrate and their results can be extrapolated outside the solved interval. Moreover, they work with a relatively low number of variables to define the state and chemical conditions in the particular zones, so requirements for hardware performance and computational time are relatively low. In particular, the adaptive numerical algorithm concerning chemical transformation of species during combustion, where a classic kinetic scheme is combined with a chemical equilibrium state if needed, would enrich the scientific branches of thermodynamics and chemistry themselves.

\section{MULTI-ZONE MODEL DESCRIPTION}

The combustion chamber is divided into $n$ zones by means of $n-1$ border surfaces in the case of a multi-zone model. Particular zones with ordinal numbers $i=1,2,3 \ldots, n$ are embedded in each other, thus they are connected subsequently as shown in Figure 1. A general chemical composition can exist in each zone, which is described by mass vector $\left\{m_{i}\right\}$, whose elements represent masses of particular chemical components with a total number of $x$. These zones can touch each other or the total volume border. Mass or heat can be exchanged between zones or between a zone and the combustion chamber surroundings. There is just one value of common cylinder pressure $p$ identical for all zones, but each zone has its own mean temperature $T_{i}$. Mixtures of ideal gases are assumed in all zones.

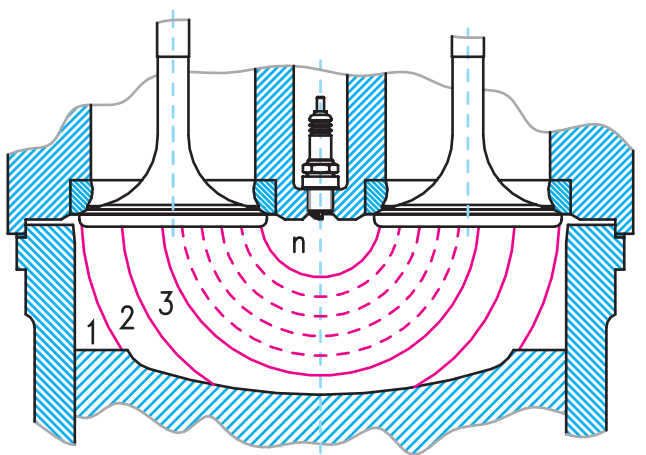

FIGURE 1: Combustion chamber divided into $n$ zones. OBRÁZEK 1: Spalovací prostor rozdělen na $n$ zón.

In this case, each zone can be considered a thermodynamic non-isolated open system and the following equations can be used for complete model description.

The mass conservation law states that a change in the mass vector of zone $i$ is given by the difference between mass input and output rates or by changes resulting from chemical processes inside a zone:

$$
\frac{d\left\{m_{i}\right\}}{d t}=\left\{m_{i-1, i}\right\}-\left\{m_{i, i+1}\right\}+\frac{d\left\{m_{i}^{c h}\right\}}{d t} .
$$

Zone-to-zone mass flows, shown in Figure 2 for the case of a three-zone model, are determined on the basis of velocities of flame borders, zone densities and mutual border areas. Here, the velocities of flame borders are calculated in an empirical way by means of turbulent coefficient $K_{\text {turb }}$ as the crucial tuning parameter of a model.

In the case of a predictive form of the multi-zone model, a suitable value or function for the turbulent coefficient $K_{\text {turb }}$ is selected to achieve an expected peak value of combustion pressure or the best possible accordance with recorded pressure trace.

In the case of an inverse form of the multi-zone model, the same simulated pressure trace difference as the difference in the trend indicated during experiments is required at every step of the numerical solution. An iterative procedure, introduced in [2], was developed to meet this requirement by means of determination of the correct value of turbulent coefficient $K_{\text {turb }}$.

The energy conservation law is the second equation used. Transferred heat is determined by means of Newton's heat transfer law and it is given by the sum of all heat fluxes to particular mechanical parts creating the combustion chamber border marked by index $j$. A heat transfer coefficient $\alpha$ can be calculated by means of Eichelberg's, Woschni's or Bargende's empirical equations. The final form of the energy conservation law of zone $i$ is then as follows: 


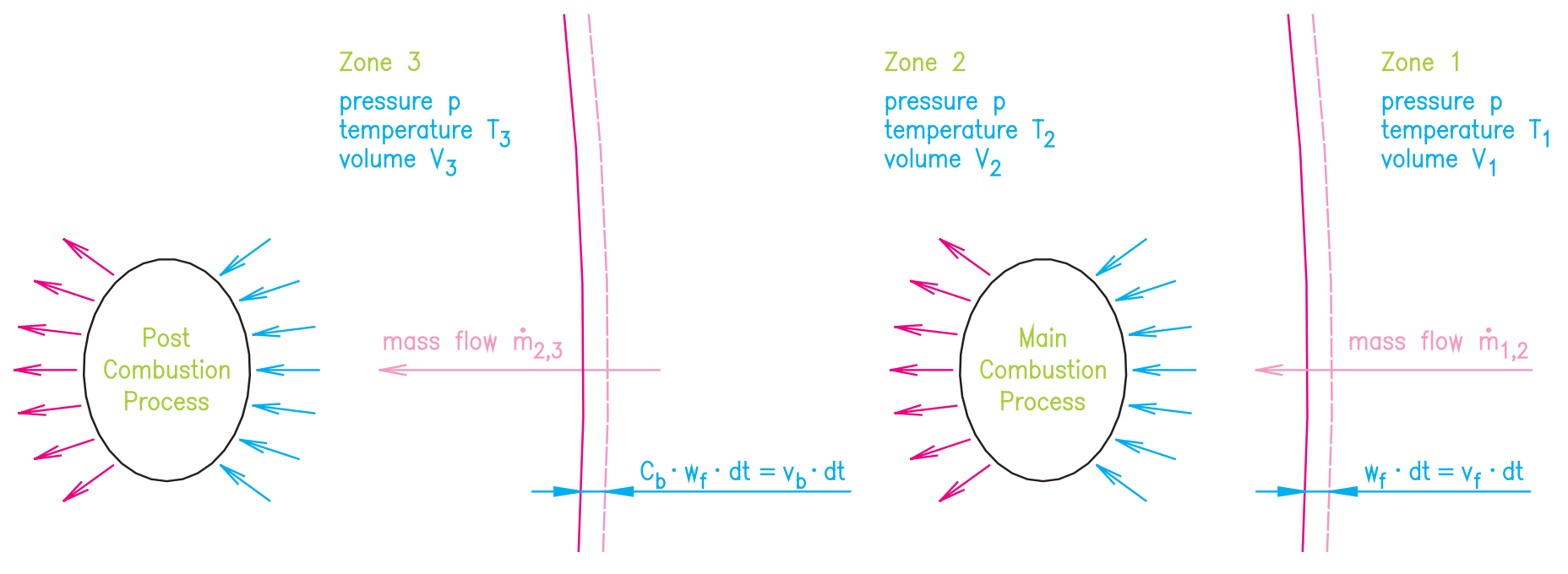

FIGURE 2: Transfer and transformation of species.

OBRÁZEK 2: Přenos a přeměna složek.

$-\sum_{j} \alpha \cdot S_{i j} \cdot\left(T_{i}-T_{j}\right)+\left\{m_{i-1, i}\right\}^{T} \cdot\left\{h_{i-1}\right\}-\left\{m_{i, i+1}\right\}^{T} \cdot\left\{h_{i}\right\}=\left\{h_{i}\right\}^{T} \cdot \frac{d\left\{m_{i}\right\}}{d t}+\left\{c_{p i}\right\} \cdot\left\{m_{i}\right\} \cdot \frac{d T_{i}}{d t}-V_{i} \cdot \frac{d p}{d t}$.

As the last equation for zone $i$, it is possible to use the state equation for the mixture of ideal gases:

$p \cdot V_{i}=\{r\}^{T} \cdot\left\{m_{i}\right\} \cdot T_{i}$,

and its differential form:

$\frac{1}{p} \cdot \frac{d p}{d t}+\frac{1}{V_{i}} \cdot \frac{d V_{i}}{d t}=\frac{\{r\}^{T}}{\{r\}^{T} \cdot\left\{m_{i}\right\}} \cdot \frac{d\left\{m_{i}\right\}}{d t}+\frac{1}{T_{i}} \cdot \frac{d T_{i}}{d t}$.

Obviously, a fixed condition is the total volume of combustion chamber, which is a function of piston kinematics only and it is always equal to the sum of volumes of all particular zones:

$V=\sum_{i} V_{i}$

The same condition also holds true for time derivatives of these volumes:

$\frac{d V}{d t}=\sum_{i} \frac{d V_{i}}{d t}$

\section{SPECIFIC APPROACH TO CHEMICAL}

\section{TRANSFORMATION}

\subsection{CHEMICAL KINETICS}

Consider the classic chemical kinetic scheme, described by means of [3], composed of $I$ simultaneously proceeding chemical reactions. An elementary reversible reaction involving $K$ chemical species can be represented in the general form:

$\sum_{k=1}^{K} v_{k i}^{\prime} \chi_{k} \leftrightarrow \sum_{k=1}^{K} v_{k i}^{\prime \prime} \chi_{k} \quad i=1,2, \ldots, \mathrm{I}$,

where the stoichiometric coefficients $v_{k i}$ are integer numbers and $\chi_{k}$ is the chemical symbol for the $k^{\text {th }}$ species. The superscript ' indicates forward stoichiometric coefficients, while " indicates reverse stoichiometric coefficients.

The production rate $\dot{\omega}_{k}$ of the $k^{\text {th }}$ species can be written as a summation of the rate-of-progress variables for all reactions involving the $k^{\text {th }}$ species:

$\dot{\omega}_{k}=\sum_{i=1}^{I} v_{k i} \cdot q_{i} \quad k=1,2, \ldots, \mathrm{K}$,

where

$v_{k i}=v_{k i}^{\prime \prime}-v_{k i}^{\prime}$ 
The rate of progress variable $q_{i}$ for the $i^{\text {th }}$ reaction is given by the difference in the forward and reverse rates as:

$q_{i}=k_{f_{i}} \cdot \prod_{k=1}^{K}\left[X_{k}\right]^{v_{k i}^{*}}-k_{r_{i}} \cdot \prod_{k=1}^{K}\left[X_{k}\right]^{v_{k i}^{*}}$,

where $\left[X_{k}\right]$ is the molar concentration of the $k^{\text {th }}$ species and $k_{f i}$ and $k_{r i}$ are the forward and reverse rate constants of the $i^{\text {th }}$ reaction. Thus, the concentration of each reactant or product species is raised to the power of its stoichiometric coefficient.

The forward rate constant for the $i^{\text {th }}$ reaction is generally assumed to have the following Arrhenius temperature relationship:

$k_{f_{i}}=A_{i} \cdot T^{\beta_{i}} \cdot \exp \left(\frac{-E_{i}}{R \cdot T}\right)$,

where the pre-exponential factor $A_{i}$, the temperature exponent $\beta_{i}$, and the activation energy $E_{i}$ are specified.

In thermal systems, the reverse rate constants $k_{r i}$ are related to the forward rate constants through the equilibrium constants by:

$k_{r_{i}}=\frac{k_{f_{i}}}{K_{c_{i}}}$.

\subsection{CHEMICAL EQUILIBRIUM}

Instead of using algebraic equations for every reaction in equilibrium, the principle of minimum Gibbs free enthalpy was used for chemical equilibrium state description. Application of Holub's method [4] using principles of bounded extremes method, known also as the Lagrangian multiplier method, can be used to find the molar fractions of species in the equilibrium condition.

In the following ideal gaseous system with $N$ chemical components with index $i=1,2, \ldots, \mathrm{N}$ and $M$ chemical elements with index $j=1,2, \ldots, \mathrm{M}$ is considered, where each element is represented by its amount $b_{j}$ determined from constitution coefficient $a_{i j}$ and molar quantity $n_{i}$. The final sum function $F$ containing Lagrangian multipliers $\pi$, to be minimized can be defined by means of Equations (13) to (16) and (17) using dimensionless functions $c_{i}$ and $f_{i}$ of the Gibbs free enthalpy $G^{0}$ corresponding to temperature $T$ :

$\Gamma(n)=\sum_{i=1}^{N} f_{i}, \quad f_{i}=n_{i} \cdot\left[c_{i}+\ln \frac{n_{i}}{n}\right]$,
$c_{i}=\left(\frac{G^{0}}{R \cdot T}\right)_{i}+\ln \frac{p}{p_{0}}, \quad b_{j}=\sum_{i=1}^{N} a_{i j} \cdot n_{i}$,

$F\left(n_{1}, \mathrm{n}_{2}, \ldots, \mathrm{n}_{\mathrm{N}} ; \pi_{1}, \pi_{2}, \ldots, \pi_{\mathrm{M}}\right)=$

$=G\left(n_{1}, \mathrm{n}_{2}, \ldots, \mathrm{n}_{\mathrm{N}}\right)+\sum_{j=1}^{M} \pi_{j} \cdot\left(b_{j}-\sum_{i=1}^{N} a_{i j} \cdot n_{i}\right)$.

The input data for this method are initial molar quantities of considered chemical components $n_{i}$, pressure $p$ and temperature $T$. The output data are new molar quantities of the considered chemical components $n_{i}$ corresponding to the state of chemical equilibrium at pressure $p$ and temperature $T$. In general, this result is obtained by solving the following equation system defined by Equations (18) and (19). A generalized Newtonian method is used for this calculation.

$\frac{\partial F}{\partial n_{i}}=0 \quad i=1,2, \ldots, \mathrm{N}$

$\frac{\partial F}{\partial \pi_{j}}=0 \quad j=1,2, \ldots, M$

\subsection{COMBINATION OF THE BOTH APPROACHES}

Utilization of a purely kinetic scheme is quite problematic in more complicated chemical systems created by a range of simultaneously running chemical reactions, where some of them have abnormally high values of reaction rates leading to chemical equilibrium state. So, there is a general effort to develop an alternative method for determination of chemical composition changes for more complex chemical systems based on the combination of a kinetic scheme and Holub's method for determination of chemical equilibrium. This algorithm, already presented in [5] and graphically shown in Figure 3, works in the following way:

- Every time step of the numerical solution is initiated by a pure kinetic scheme and the rate of progress variables $q_{i}$ for all reactions are calculated using Equation (10).

- Time derivatives of molar concentrations are determined by means of production rates $\dot{\omega}_{k}$ from Equation (8).

- A trial integration of molar concentrations is performed and the possible presence of their negative values is checked.

- In the positive case, the reactions most responsible for negative molar concentrations are selected on the basis of values of rate of progress variables $q_{i}$. These selected reactions are excluded from the kinetic scheme (their 
rate of progress variables are set to 0 ).

- The kinetic part of the numerical step and reactions rejection process is repeated until there is no negative molar concentration after the trial integration.

- The chemical equilibrium state is calculated using the flexible Holub's method for reactants belonging to all excluded reactions.

- At the end of the numerical step, the chemical equilibrium state is calculated by means of flexible Holub's method for reactants belonging to all excluded reactions and new molar concentrations determined by means of the limited kinetic scheme are completed by an equilibrium molar concentration vector.

\section{GEOMETRICAL CHARACTERISTICS}

The differential-algebraic equation system described above contains a large number of geometrical quantities, which have to be supplied at every step of the numerical calculation. That is why data files containing tabulated values of these quantities and named geometrical characteristics have to be created.

Geometrical characteristics are defined by the relationship between a quantity with a geometrical character and three independent variables, which are:

- Crankshaft angle $\alpha$

- Radius of forward spherical border surface $r_{i}$

- Radius of backward spherical border surface $q_{i+1}$

Subtraction of volumes and surfaces can be used to decrease the number of independent variables for tabulation of geometrical characteristics, because the general geometrical characteristics always contain the entire data from the center of the spherical boundary surface to this boundary surface. This principle is shown in Figure 4 and the example of general geometrical characteristics, defined just by a crankshaft angle $\alpha$ and radius of spherical boundary surface $r$, for the case of volume of zone $i$ is presented in Figure 5 .

The number and types of used geometrical characteristics depend on the requirements resulting from the differential-algebraic

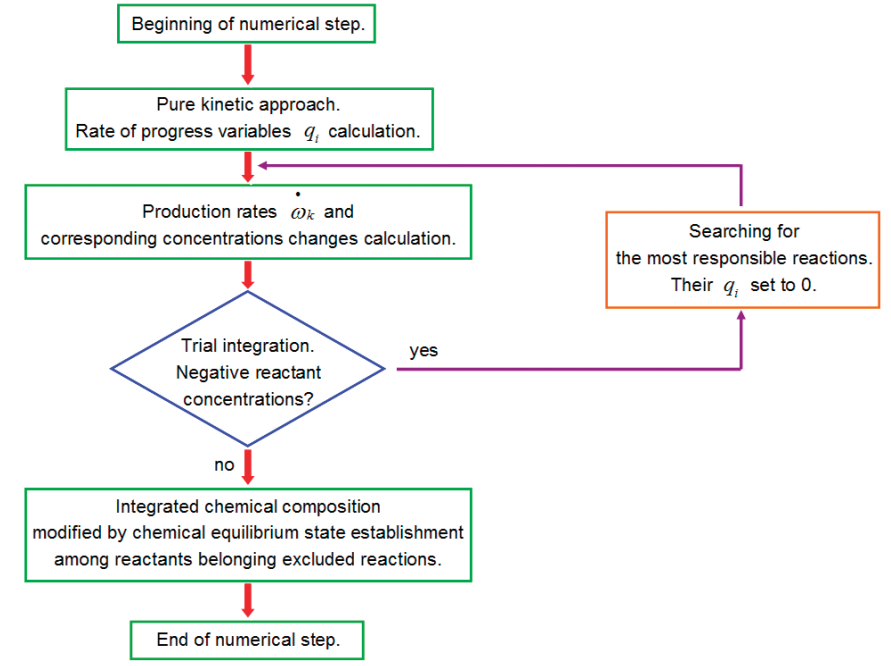

FIGURE 3: Numerical step flow chart.

OBRÁZEK 3: Vývojový diagram numerického kroku.

equation system. In general, it is necessary to substitute the volumes of particular zones and of the entire combustion chamber, areas of border surfaces between zones and heat transfer areas of zones determined by combustion chamber walls. Additionally, a cylinder liner is divided into eight levels to take into account the variability of its surface temperature.

So, the total number of geometrical characteristics is 15: total volume of the combustion chamber, volume of zone $i$, area of the border surface between zones $i$ and $i-1$ and heat transfer areas between zone $i$ and inlet valve, exhaust valve, piston, cylinder head and cylinder liner levels 1 to 8 .

General geometrical characteristics are the set of values of given geometrical quantity, which have to be determined in the intersections of a planar grid, whose sides are created by discrete values of the above-mentioned two independent variables. Therefore, it was necessary to find a CAD software package allowing the modeling of all combinations of these coordinates including data storage. The choice of AutoLisp programming language [6] proved to be a suitable solution.

Currently, there are two general options for geometrical characteristics generation:
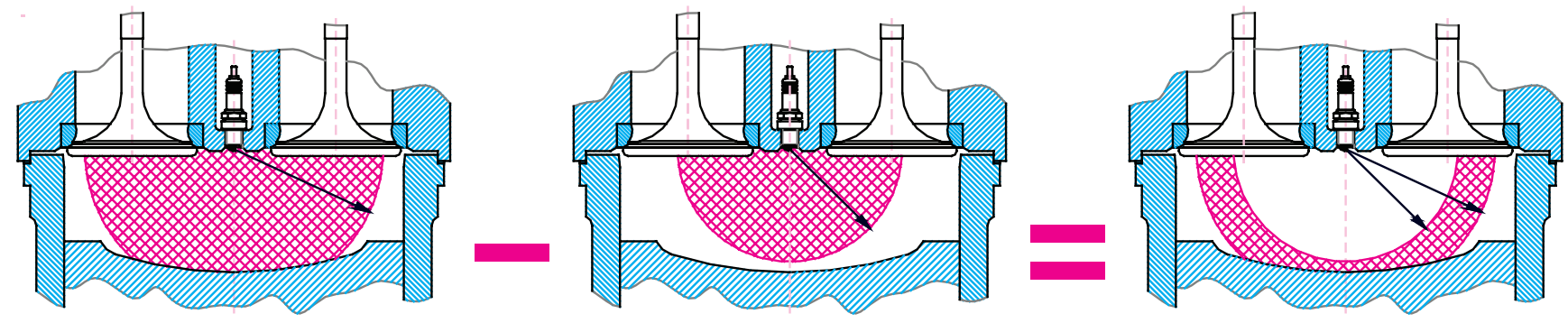

FIGURE 4: Geometrical characteristics obtained by means of subtraction.

OBRÁZEK 4: Geometrické charakteristiky získané pomocí odečítání. 


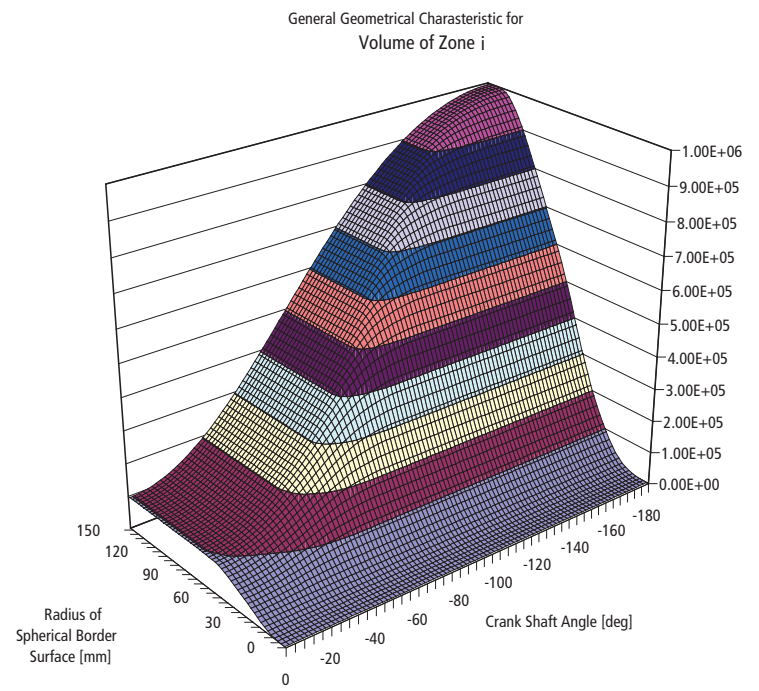

FIGURE 5: General geometrical characteristics for volume of zone i.

OBRÁZEK 5: Zobecněné geometrické charakteristiky pro objem zóny i.
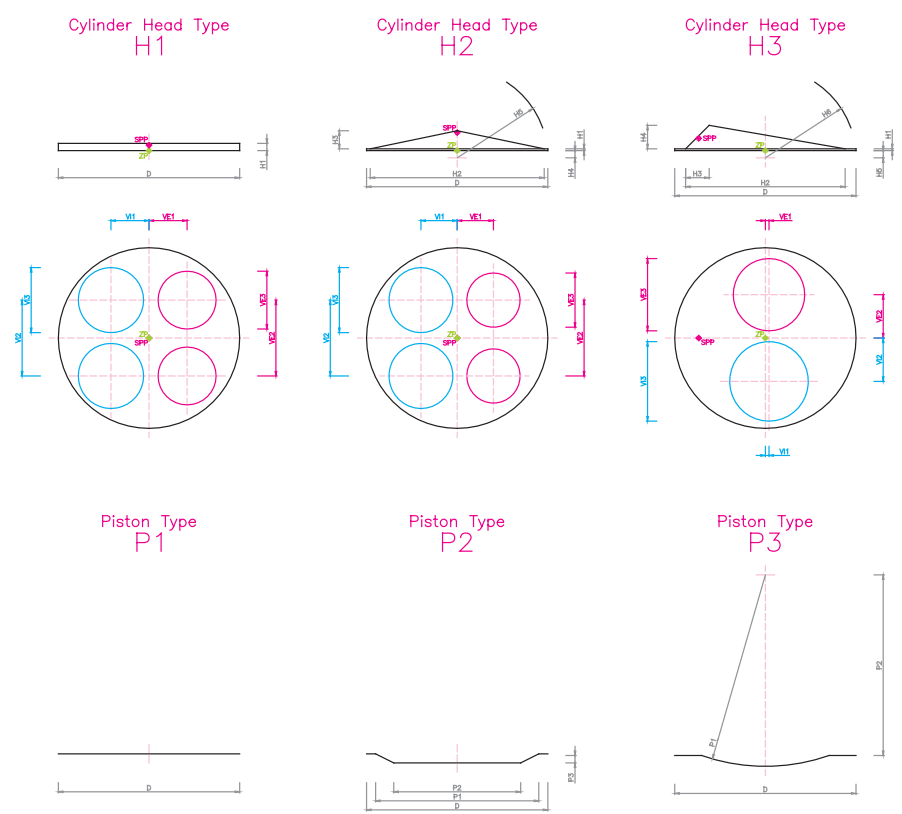

FIGURE 6: GeoGen - available types of cylinder head and piston. OBRÁZEK 6: GeoGen - dostupné typy hlavy válce a pístu.

- Where there is detailed knowledge of the actual combustion chamber geometry, a customized geometrical characteristics generator can be prepared.

- GeoGen - a newly created parametric generator for geometrical characteristics. This tool is suitable mainly at the early-stage of engine design, where plenty of different combustion chamber geometry variants would be examined, or in the case of unknown actual combustion chamber geometry. The most suitable shape is chosen from a library as a combination of cylinder head and piston type described by a number of parameters.

\section{RESULTS}

\subsection{SPECIES CHEMICAL TRANSFORMATION}

The functionality of the above introduced procedure was checked for a relatively simple reaction mechanism belonging to hydrogen combustion. The complete mechanism of this chemical transformation consists of 23 reactions involving 11 species. The following detailed reaction mechanism description and corresponding chemical kinetic and thermodynamic data are obtained by means of [3]:

$\begin{array}{ll}01 & \mathrm{H} 2+\mathrm{O} 2=2 \mathrm{OH} \\ 02 & \mathrm{OH}+\mathrm{H} 2=\mathrm{H} 2 \mathrm{O}+\mathrm{H} \\ 03 & \mathrm{O}+\mathrm{OH}=\mathrm{O} 2+\mathrm{H} \\ 04 & \mathrm{O}+\mathrm{H} 2=\mathrm{OH}+\mathrm{H} \\ 05 & \mathrm{H}+\mathrm{O} 2+\mathrm{M}=\mathrm{HO} 2+\mathrm{M} \\ 06 & \mathrm{OH}+\mathrm{HO} 2=\mathrm{H} 2 \mathrm{O}+\mathrm{O} 2 \\ 07 & \mathrm{H}+\mathrm{HO} 2=2 \mathrm{OH} \\ 08 & \mathrm{O}+\mathrm{HO} 2=\mathrm{O} 2+\mathrm{OH} \\ 09 & 2 \mathrm{OH}=\mathrm{O}+\mathrm{H} 2 \mathrm{O} \\ 10 & 2 \mathrm{H}+\mathrm{M}=\mathrm{H} 2+\mathrm{M} \\ 11 & 2 \mathrm{H}+\mathrm{H} 2=2 \mathrm{H} 2 \\ 12 & 2 \mathrm{H}+\mathrm{H} 2 \mathrm{O}=\mathrm{H} 2+\mathrm{H} 2 \mathrm{O} \\ 13 & \mathrm{H}+\mathrm{OH}+\mathrm{M}=\mathrm{H} 2 \mathrm{O}+\mathrm{M} \\ 14 & \mathrm{H}+\mathrm{O}+\mathrm{M}=\mathrm{OH}+\mathrm{M} \\ 15 & 2 \mathrm{O}+\mathrm{M}=\mathrm{O} 2+\mathrm{M} \\ 16 & \mathrm{H}+\mathrm{HO} 2=\mathrm{H} 2+\mathrm{O} 2 \\ 17 & 2 \mathrm{HO} 2=\mathrm{H} 2 \mathrm{O} 2+\mathrm{O} 2 \\ 18 & \mathrm{H} 2 \mathrm{O} 2+\mathrm{M}=2 \mathrm{OH}+\mathrm{M} \\ 19 & \mathrm{H} 2 \mathrm{O} 2+\mathrm{H}=\mathrm{HO} 2+\mathrm{H} 2 \\ 20 & \mathrm{H} 2 \mathrm{O} 2+\mathrm{OH}=\mathrm{H} 2 \mathrm{H}+\mathrm{HO} 2 \\ 21 & \mathrm{O}+\mathrm{N} 2=\mathrm{NO}+\mathrm{N} \\ 22 & \mathrm{~N}+\mathrm{O} 2=\mathrm{NO}+\mathrm{O} \\ 23 & \mathrm{OH}+\mathrm{N}=\mathrm{NO}+\mathrm{H} \\ & \end{array}$

The proposed algorithm combining chemical kinetics and chemical equilibrium is processed in a numerical way using the second order Runge-Kutta method and the Fortran 77 programming language. The selected results from the test example with the following features are presented:

- Stoichiometric combustion of hydrogen-air mixture.

- Initial temperature of $1000 \mathrm{~K}$ and pressure of $100 \mathrm{kPa}$.

- Combustion chamber volume of 1 liter.

Molar concentration trends for particular species during the combustion are shown in Figure 7. The stoichiometric ratio of fuel-oxidizer mixture results in a very low amount of residual oxygen 02 . The high flame temperature causes a sizable content of dissociated gases, monoatomic species $\mathrm{H}$ and $\mathrm{N}$ in the range of $10 \mathrm{E}-3$, monoatomic 0 in the range of $10 \mathrm{E}-5$. The equilibrium amount of hydroxyl radical $\mathrm{OH}$ reaches the range of $10 \mathrm{E}-6$. 
Also the activity of the Zeldovich mechanism, represented by the last three reactions of the reaction mechanism, is supported by high temperature leading to a content of nitric oxide NO in the range of $10 \mathrm{E}-3$.

The reactions and corresponding reactant species excluded from the kinetic scheme during the calculation are marked by the value 1 in Figure 8. Two lines for every point of numerical solution correspond to the first and the second step of the second order Runge-Kutta method. Using the simplified method, three groups of chemical reactions can be distinguished. First, there are the reactions proceeding slowly, which are never excluded from the kinetic scheme. Secondly, abnormally fast reactions responsible for negative reactant concentrations, which are routinely excluded. In between, there are reactions, whose rejection varies depending on the process of a two-step numerical method.

\subsection{INVERSE MODEL FORM USED FOR EVALUATION OF EXPERIMENTS}

In this case, the essential input data were available from a gasoline fuelled spark ignition ŠKODA engine with $2 \mathrm{~V}$ cylinder head version. All the presented results relate to the measured engine operation point with fully opened throttle, stoichiometric fuel-air mixture and speed of $4500 \mathrm{rpm}$.

The plots of combustion pressure and its derivative are shown in Figure 9. Two data sources are available. An indicated experimental combustion pressure (marked EX) was measured and used for calibration of the code using the inverse form

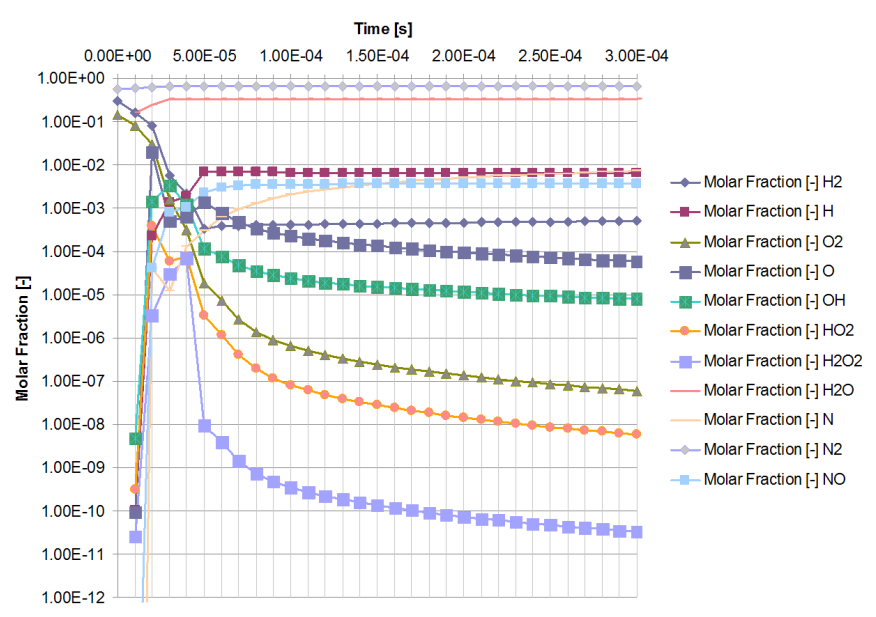

FIGURE 7: Molar fractions.

OBRÁZEK 7: Molární zlomky.

of the two-zone model (marked ZM). In the combustion area, the inverse model is able to follow the indicated combustion pressure trend by means of the turbulence coefficient and turbulent flame velocity presented in Figure 10. During the compression stroke up to the point of ignition, experimental combustion pressure is used directly and temperature of cylinder contents is calculated by means of the state equation. The most interesting and important outputs of the inverse multi-zone model are shown in Figure 10. Evolution of the border radius between zones 1 and 2 can be seen here. The time derivative of this trend corresponds to the final flame

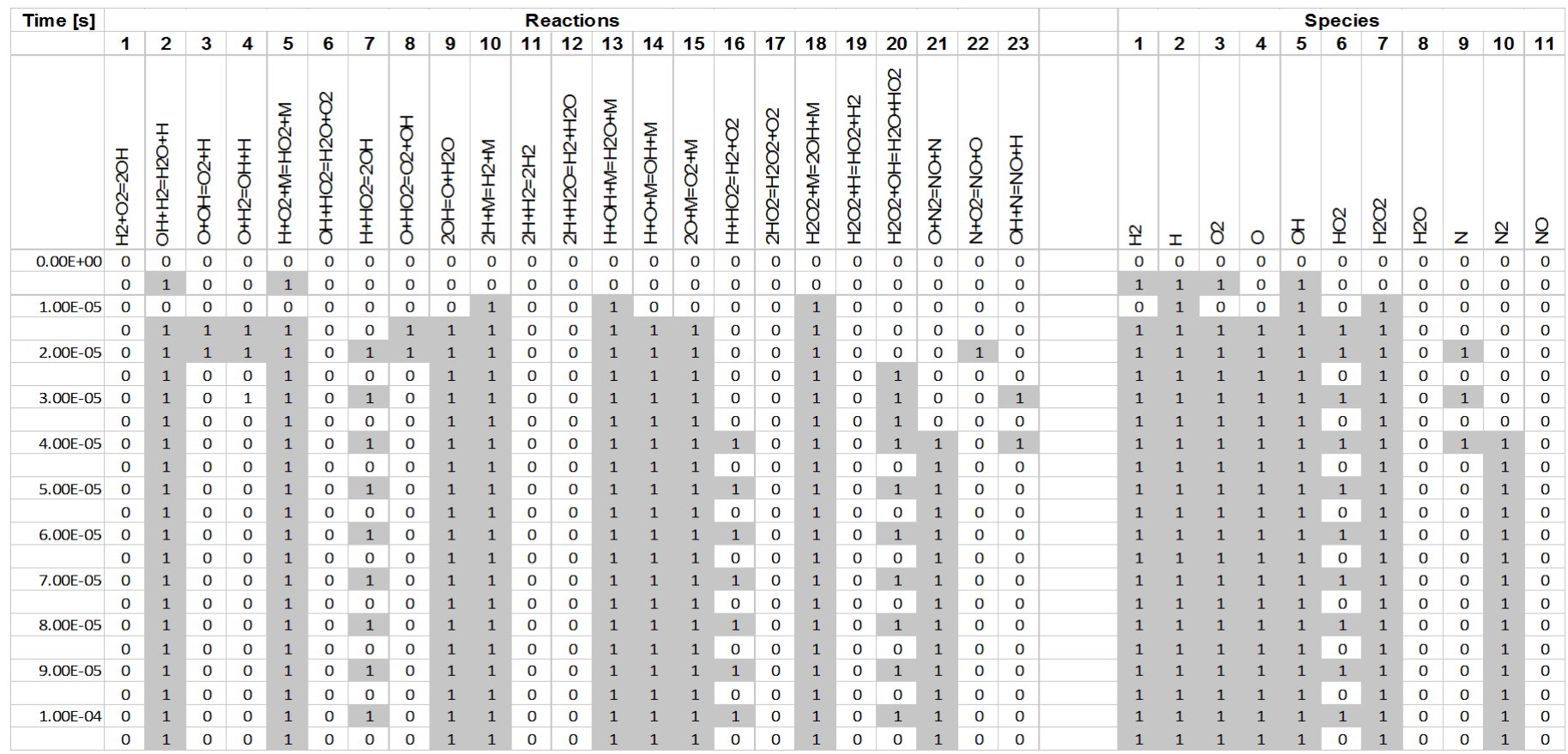

FIGURE 8: Excluded reactions and species.

OBRÁZEK 8: Vyloučené reakce a složky. 


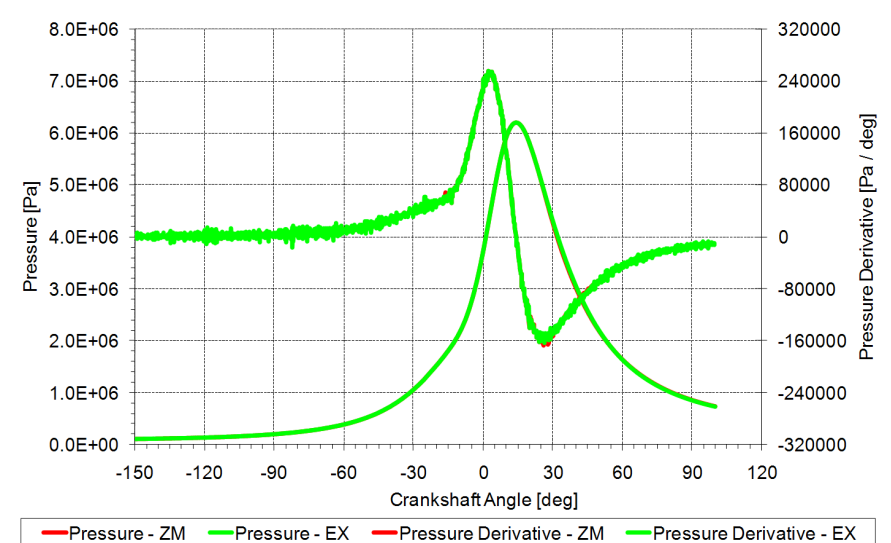

FIGURE 9: Pressure and pressure derivative. OBRÁZEK 9: Tlak a tlaková derivace.

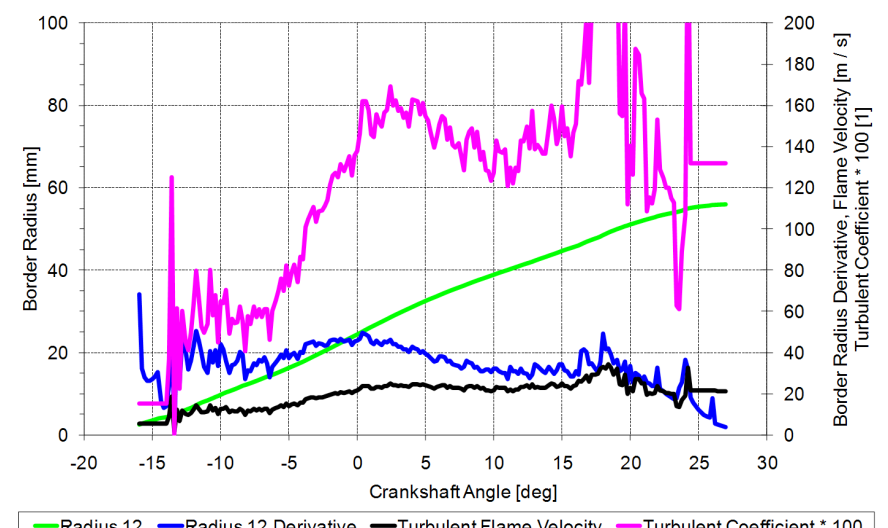

FIGURE 10: Boundary radius, its derivative, turbulent flame velocity and turbulent coefficient.

OBRÁZZKK 10: Hraniční rádius, jeho derivace, turbulentní rychlost plamene a turbulentní koeficient.

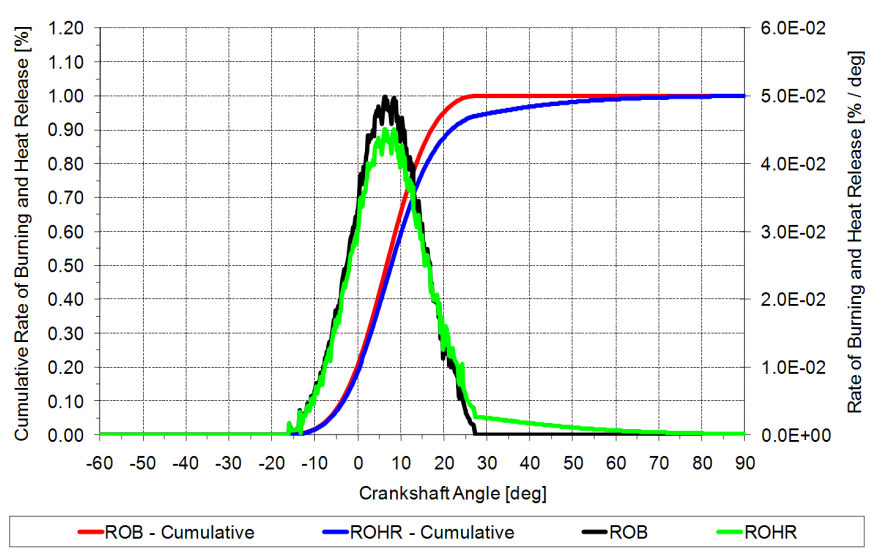

FIGURE 11: ROB and ROHR and their cumulative curves. OBRÁZEK 11: ROB a ROHR a jejich kumulativní křivky. front velocity composed of turbulent flame velocity added to the flame front shift caused by expansion of combustion products behind this front. As can be seen, the turbulent entrainment flame velocity achieves values of around $10-30 \mathrm{~m} / \mathrm{s}$ across almost the whole combustion area, while total flame propagation velocity is approximately double this as a result of expansion effects. Once at the end of combustion, both velocities are almost the same.

The plots of corresponding ROB and ROHR curves and their cumulated values are shown in Figure 11. The additional heat release at the end of combustion, when the fuel itself is already involved in reactions, is caused by reactions related to the establishment of chemical equilibrium states in the flame front and combustion products region - zone 2 .

\section{CONCLUSION}

The presented results demonstrate the positive features of the model, which can be used for predicting simulations or evaluation of experiments. A differential-algebraic equation system was derived by means of the mass conservation law, energy conservation law, state equation and empirical equations for calculation of heat transfer coefficient and turbulent flame velocity to describe a multi-zone model of combustion and heat transfer processes in a spark ignition engine. The generalized procedure for participation of chemical kinetics and chemical equilibrium was introduced here to address the numerical issues connected with a purely kinetic scheme. A tool, introducing an interesting alternative for simulation of the high-pressure part of the thermodynamic cycle in a four-stroke spark ignition engine, was thus created.

At this moment, there are two options to cover all geometrical requirements of the equation system describing the multi-zone model, both created using the AutoLisp programming language to be able to generate solids of particular zones for the given combustion chamber geometry and to create data files with geometrical characteristics containing corresponding volumes and areas. The first is a customized code for real combustion chamber geometry. The second is a GeoGen parametric generator equipped with the basic combustion chamber shapes.

The predictive form of the multi-zone model is intended as an interesting alternative for simulating computations of the high-pressure part of the thermodynamic cycle in a four-stroke combustion engine. In the near future, its implementation into simulating codes, mainly [7], is planned. Thus, it will be possible to use it for complex engine and power train simulations.

The early-stage of engine design, particularly concerning valve size and lay-out, spark plug position, the influence of combustion chamber shape on engine performance and thermal stress of parts creating the combustion chamber, is the domain where the predictive multi-zone model represents a very useful tool. 
Moreover, knowledge of conditions concerning compression of the fresh mixture due to expanding combustion products, its location and its surroundings defining heat transfer between the fresh mixture and surroundings brings the valuable possibility of engine knocking prediction.

The inverse form of the multi-zone model uses presented equations in the same format as in the case of the predictive code. The procedure has been developed to determine the appropriate value of turbulence coefficient at every step of numerical integration to achieve the measured increment of pressure in a combustion chamber. It provides the crucial tuning model parameters. Using these results, the almost perfect correspondence between calculated and measured combustion pressure can be achieved.

Thus, the inverse form of the multi-zone model of combustion and heat transfer processes represents an efficient tool for quantitative estimates regarding intensity of the turbulent flow field inside the combustion chamber and important combustion features of various fuels.

\section{ACKNOWLED GEMENTS}

This research has been realized using the support of EU Regional Development Fund in OP R\&D for Innovations (OP VaVpl) and Ministry for Education, Czech Republic, project \# CZ.1.05/2.1.00/03.0125 Acquisition of Technology for Vehicle Center of Sustainable Mobility and the support of Technological Agency, Czech Republic, programme Centres of Competence, project \# TE01020020 Josef Božek Competence Centre for Automotive Industry. These supports are gratefully acknowledged.

\section{REFERENCES}

[1] Hvězda J. (2011). Multi-Zone Models of Combustion and Heat Transfer Processes in SI Engine, SAE Torino Group, TO ZEV 2011, SAE Paper 2011-37-0024.

[2] Hvězda J. (2010). Inverse Form of Multi-Zone Model of Combustion and Heat Transfer Processes in SI Engine, Sborník z mezinárodní konference KOKA 2010, Liberec 2010.

[3] Kee R. J., Rupley F. M., Miller J. A., Coltrin M. E., Grcar J. F., Meeks E., Moffat H. K., Lutz A. E., Dixon-Lewis G., Smooke M. D., Warnatz J., Evans G. H., Larson R. S., Mitchell R. E., Petzold L. R., Reynolds W. C., Caracotsios M., Stewart W. E., Glarborg P., Wang C. \& Adigun 0. (2000). CHEMKIN Collection, Release 3.6, Reaction Design, Inc., San Diego, CA 2000.

[4] Holub R. (1972). Chemická rovnováha plynných reakcí, Academia, Praha 1972.

[5] Hvězda J. (2011):: Species Chemical Transformation Description Using Combination of Chemical Kinetics and Chemical Equilibrium, Sborník z mezinárodní konference KOKA 2011, Žilina 2011.

[6] Bečka J. (1996). Programování pro CAD I, Vydavatelství ČVUT, Praha.

[7] GT-Power, User's Manual and Tutorial, GT-Suite TM version 6.2., Gamma Technologies Inc., 2006.

[8] Heywood J. B. (1988). Internal Combustion Engine Fundamentals, McGraw-Hill, London. 